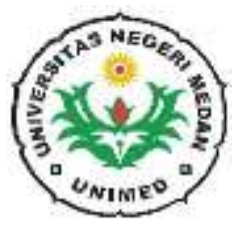

\author{
JBIO: JURNAL BIOSAINS \\ (The Journal of Biosciences) \\ http://jurnal.unimed.ac.id/2012/index.php/biosains \\ email : jbiosains@unimed.ac.id \\ unimed.ac.id
}

\title{
DNA BARCODING EDELWEISS (Anaphalis longifolia) ASAL SUMATERA UTARA MENGGUNAKAN SEKUEN GEN maturase $\mathrm{K}$
}

\author{
Eko Prasetya', Hary Prakasa', Miftahul Jannah ${ }^{2}$, Yuanita Rachmawati ${ }^{3}$ \\ ${ }^{1}$ Department of Biology, Faculty of Mathematics and Natural Sciences, Universitas Negeri Medan, Jl. Willem \\ Iskandar, Pasar V, Medan Estate, Medan, 20221, North Sumatera, Indonesia \\ ${ }^{2}$ Department of Biology, Faculty of Sciences and Technology, Islamic University of As-syafiiyah, Jl. Jatiwaringin \\ Raya, No 12, East Jakarta, Indonesia \\ ${ }^{3}$ Department of Biology, Faculty of Sciences and Technology, Islamic State University Sunan Ampel Surabaya, \\ Jl. Ahmad Yani 117 Surabaya, East Java, Indonesia \\ email korespondensi: ekoprasetya.biologi@gmail.com
}

Diterima: Oktober 2020; Direvisi: November 2020; Disetujui: Desember 2020

\begin{abstract}
Anaphalis longifolia merupakan anggota dari family Asteraceae yang tersebar di dataran tinggi Eropa, Amerika, hingga Asia. Penelitian tentang tanaman ini masih terbatas pada studi habitat, sedangkan penelitian terkait identifikasi molekuler masih belum dilakukan. Penelitian ini bertujuan untuk menganalisis DNA barcode dari A. longifolia menggunakan sekuen matK gene. Sampel yang diperoleh dari Sumatera Utara kemudian di Isolasi DNA, di amplifikasi menggunakan primer spesifik, lalu disequencing. Hasil sequencing dianalisis menggunakan program Molecular Evolution Genetics Analysis (MEGA) Version X. Hasil penelitian menunjukkan bahwa sekuen matK gen berhasil diamplifikasi pada panjang 800-850 kb. Hasil analisis pohon filogenetik menunjukkan bahwa sekuen matK gene dapat mengelompokkan $A$. longifolia. Pada sekuen matK gene $A$. longifolia, AT content lebih tinggi dibandingkan dengan GC conten. Jarak genetik yang diperoleh berkisar 0-0.0014. Hasil analisis alignment sekuen matK gene menunjukkan terdapat 1521 karakter yang dapat diamati, 1403 karakter conserved site, 118 karakter variable site, 9 karakter parsimony informative site, dan 7 karakter single nucleotide polymorphism (SNP) site. Sekuen matK gene dapat digunakan sebagai DNA barcoding untuk mengidentifikasi $A$. longifolia. Hasil penelitian ini diharapkan dapat memberikan informasi penting dalam konservasi A. longifolia.
\end{abstract}

Keywords: Anaphalis longifolia, matK, DNA barcoding, Sumatera Utara

\section{DNA BARCODING OF EDELWEISS (Anaphalis longifolia) OF NORTH SUMATRAN ORIGIN USING SEQUENCE Maturase K GENE}

\begin{abstract}
Anaphalis longifolia is a member of the Asteraceae family found throughout the highlands of Europe, America and Asia. Studies on this plant is still limited to their habitat, whereas its molecular identification is largely unknown. This study aims to analyze the DNA barcode of $A$. longifolia using the matK gene sequence. DNA of the samples obtained from North Sumatra were isolated and then amplified using specific primers, and eventually sequenced. The results of sequencing were analyzed using the Molecular Evolution Genetics Analysis (MEGA) program Version X. The results showed that the matK gene sequence was successfully amplified at a length of 800-850 kb. The results of the phylogenetic tree analysis show that the matK gene sequence is capable of classifying $A$. longifolia. In the A. longifolia matK gene sequence, the AT content was
\end{abstract}


higher than GC. The genetic distance obtained from the sequencing ranges from $0-0.0014$. The results of matK gene sequence alignment analysis show that there were 1521 observable characteristics, 1403 conserved site characteristics, 118 site variable characteristics, 9 parsimony informative site characteristics, and 7 single nucleotide polymorphism (SNP) site characteristics. The matK gene sequence can be used in DNA barcoding to identify A. longifolia. The results of this study are expected to provide important information in A. longifolia conservation attempts.

\section{Keywords: Anaphalis longifolia, matK, DNA barcoding, North Sumatra}

\section{Introduction}

Anaphalis is a member of the Asteraceae family (Tjitrosoedirdjo, 2002) widespread across mountainous areas in the continents of Europe, America, and even Asia (Chanchani et al., 2011). Anaphalis thrives at an altitude between 800 to 3400 asl (Backer \& van den Brink, 1965). Most of this genus can be found in the highlands and mountains (Prakasa et al., 2018). Due to its ability to thrive in a nutrient-poor environment, Anaphalis is considered to have high ecological value (Aliadi et al., 1990).

From 2001 to 2019, North Sumatra has lost $23 \%$ (1.33 Mha) of its tree coverage, which is equivalent to the ability to absorb $549 \mathrm{Mt}$ of $\mathrm{CO}_{2}$ emissions. Mandailing Natal Regency is the region with the most reduction in tree coverage (147 Kha) (Global Forest Watch, 2020). Forest degradation and climate change are the main causes of the increasing difficulty of finding Anaphalis. In addition to its habitat in critical environments, $A$. longifolia is also a plant with low seed viability, making it difficult to conserve. Besides that, $A$. longifolia also has very slow growth.

Plant identification using barcoding DNA is one tool that can be used in conservation efforts. Barcoding DNA is used to identify, inventory and study specimens to understand species diversity and evaluate the genetic variability of species (Krishna Krishnamurthy \& Francis, 2012). With barcoding DNA, researchers can identify species more quickly and thoroughly in order to take the appropriate action for establishing the right scale for conservation. (Francis et al., 2010).

The matK gene is a plant DNA barcode recommended by Barcode of Life (CboL). It is one of the fastest growing plastid encoders and consistently shows high levels of discrimination towards angiosperm species. (Fazekas et al., 2008; Lahaye et al., 2008a). (Li et al., 2011) stated that a combination of plastid markers including rbcl, matK and trnHpsbA could be used as DNA barcoding with a success rate of 87.1-92.7\%. According to (Hollingsworth et al., 2009), matK markers can be used to identify angiosperms (90\%), gymnosperms (83\%), and cryptogams $(10 \%)$. In Indonesia, the matK marker has been used for identifying Aeridinae (Orchidaceae) subtribe. (Topik et al., 2005), Myristica fragrans (Tallei \& Kolondam, 2015), Dipterocarpaceae (Harnelly et al., 2018), palm (Abbas et al., 2020), and Andrographis paniculata (Arif et al., 2019).

Anaphalis longifolia is a member of the genus Anaphalis (Koster, 1941). IUCN Redlist (2008) classified Anaphalis spp as threatened or endangered plants. Research related to $A$. longifolia is still limited to its ecological status and distribution (Taufiq et al., 2013). The use of matK gene DNA barcoding to identify this species has not yet been done before. This study aims to analyze the potential of the matK gene as barcoding DNA of A. longifolia plants from North Sumatra. This research is expected to provide important information on how to identify A. longifolia in its conservation effort in North Sumatra.

\section{Materials and Methods A. longifolia Samples}

2 samples of A. longifolia were obtained from Taman Eden in Toba Samosir regency and Bukit Sipiso Piso in Simalungun regency, North Sumatra. A total of 8 data from NCBI were used ingroup, namely that of Anaphalis margaritacea (HQ594564), Anaphalis aureopunctata (MH659925.1), Anaphalis aureopunctata (MH714290.1), Anaphalis sinica (MH659676.1), Anaphalis sinica (KX148081.1), Anaphalis margaritacea (MG224815), Anaphalis margaritacea (HM445632), and Helianthus annuus (AY215805.1) outgroup.

\section{DNA Extraction}

Fresh leaves from A. longifolia were extracted using the Geneaid Plant DNA Isolation Kit following the kit protocol. A total of $100 \mathrm{mg}$ of plant leaf tissue was crushed and then put into a $1.5 \mathrm{ml}$ microcentrifuge tube and added $400 \mu \mathrm{l}$ of lysis buffer GP1 and $5 \mu \mathrm{l}$ of RNase A. After homogenizing and incubating at $60^{\circ} \mathrm{C}$ for 10 minutes, $200 \mathrm{l}$ of elution buffer and $100 \mu \mathrm{l}$ of GP2 buffer were added. The mixture was then transferred to a column filter in a 2 $\mathrm{ml}$ collection tube and then centrifuged at a rate of $1,000 x g$ for 1 minute. The column filter containing 
the supernatant was removed and replaced with a new column filter. The solution in the collection tube was moved to a new filter column and $150 \%$ buffer GP3 was added to the solution volume. GD Column and the collection tube were then centrifuged at a speed of $16,000 \mathrm{x}$ g for 2 minutes. DNA was washed 2 times using W1 buffer and wash buffer. The DNA in the GD column was then eluted using a $100 \mu$ l elution buffer which had been heated at $60^{\circ} \mathrm{C}$. The collection tube was then replaced with a microcentrifuge tube. After being centrifuged again at a speed of $16,000 \mathrm{x} g$ for 30 seconds, the DNA that had entered the $1.5 \mathrm{ml}$ microsentrifuge tube was then stored at $-20^{\circ} \mathrm{C}$.

\section{DNA Amplification}

The matK sequence was amplified using matK-F 5'-ACC CAG TCC ATC TGG AAA TCT TGG TTC3 'and matK-R 5'-CGT ACA GTA CTT TTG TGT TTA CGA G-3' primers (Ki-Joong Kim, School of Life Sciences and Biotechnology, Korea University, Korea, unpublished). Amplification was carried out using the MyTaq HS Red Mix (Bioline) kit with a total reaction of $25 \mu \mathrm{l}(2.5 \mu \mathrm{l}$ of DNA template; $2.5 \mathrm{l}$ matKF primer; $2.5 \mu \mathrm{l}$ of matK-R primer; $5 \mu \mathrm{l}$ of distilled water; $12.5 \mu \mathrm{l}$ of PCR Mix). Amplification of the matK sequence was carried out at the predenaturation stage at $97^{\circ} \mathrm{C}$ for 5 minutes, denaturation at $94^{\circ} \mathrm{C}$ for 1.5 minutes, annealing at $52^{\circ} \mathrm{C}$ for 1 minute and extension at $72^{\circ} \mathrm{C}$ for 1 minute. PCR results were visualized using agarose gel. PCR products which showed clear DNA bands were to be sent to FirstBase DNA Sequencing Service in Singapore for sequencing.

\section{Data Analysis}

The sequencing results in the form of a chromatogram were edited using Bioedit 7.0.1 to obtain a consensus sequence based on the conservative sequences generated from the primary sequencing results of matK-F and matK-R. The consensus sequence that has been obtained was then aligned using Basic Local Alignment Search Tool (BAST) from the National Center for Biotechnology Information. Data with high similarity to the sample were included in the phylogenetic tree analysis. Phylogenetic trees were constructed using the Molecular Evolutionary Genetics Analysis (MEGA) X program (Kumar et al., 2018). Analyzes were performed to calculate the percentage of similarity, GC content, and genetic distance.

\section{Result and Discussion}

We succeeded in amplifying the matK gene sequence from the total genome of A. Longifolia, which would then be analyzed as DNA barcode (Figure 1). The amplification results ranged from 800-850 kb.

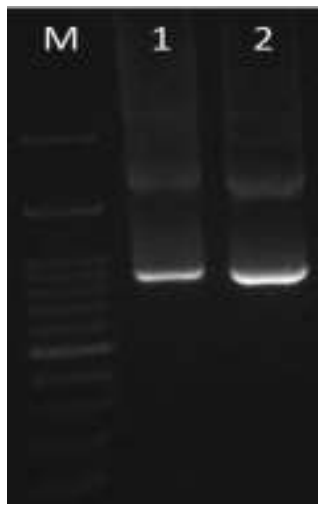

Figure 1. The results of visualization of A. longifolia matK gene PCR product using $1 \%$ agarose gel with 1 $\mathrm{kb}$ marker

PCR products that have shown positive visualization results using agarose gel were then sequenced. After the sequencing results were analyzed using BLAST on NCBI, it was found that data with high similarity to the sample were primarily from the Asteraceae family. Species with a high level of similarity according to BLAST analysis were Anaphalis margitacea (99.87\%), Anaphalioides mariae (99.87\%), Anaphalis hancockii (99.75\%), Helichrysum felinum (99.62\%) Anahalis aureopunctata (99.40\%), and Anaphalis sinica (99.15\%). Phylogenetic studies show that Anaphalis is very close to Helichrysum and Pseudognaphalium (Smissen et al., 2011; Ward et al., 2009). The results of the BLAST analysis, which showed species variation, indicated that the matK marker is not every effective when used as DNA barcoding on $A$. longifolia. Some researchers suggested a combination of the matK and rbcl markers in determining DNA barcode (Saarela et al., 2013; Wattoo et al., 2016; Hollingsworth et al., 2009; Techen et al., 2014).

In a previous study using the same primer as this one, the said primer has succeeded in identifying $35 \%$ herbarium specimens and $45 \%$ fresh specimens consisting of 900 vascular plants from 51 families, 24 orders, 147 genera, and 312 species. (Kuzmina et al., 2012). The use of this primer on Indonesian plants has been performed on Annonaceae (18 samples), Apocynaceae ( 7 samples), Dipterocarpaceae (12 samples), Lauraceae (6 samples), Meliaceae (7 samples), Moraceae (7 samples), Myristicaceae (12 samples), Phyllanthaceae (1 sample), Primulaceae (4 samples), and Rubiaceae (7 samples) plants (Dean et al., 2018). Especially in Sumatra, this primer has 
successfully amplified 441 species, 97 families and 40 orders of flowering plants (Amandita et al., 2019).

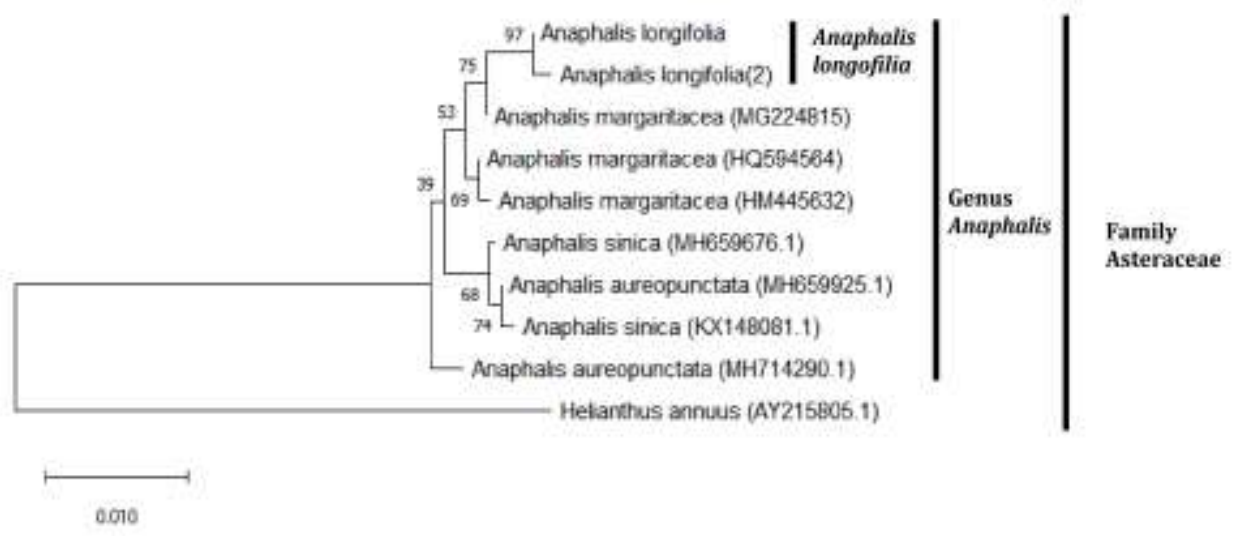

Figure 2. Phylogenetic tree based on the matK gene sequence of Anaphalis longifolia with the Helianthus annuus outgroup reconstructed using the Neighbor Joining method, with the evolutionary distance calculated using the Kimura 2-parameters method (Kimura, 1980). Percentage of species-replicating trees under bootstrap test (1000 replicates) ) (Felsenstein, 1985).

The phylogenetic tree in Figure 2 shows that the matK gene sequence in $A$. longifolia can distinguish this species from other Anaphalis genus and from Helianthus annuus as an outgroup of the Asteraceae family. This shows that the matK gene has the potential to be used as DNA barcoding for $A$. longifolia, but it is less effective when used to distinguish between species in the anaphalis genus.
Analysis using clustal $\mathrm{W}$ in the MEGA $\mathrm{X}$ application shows that there are 1521 characteristics that can be observed. From this data, there are 1403 conserved sites characteristics, 118 site variables characteristics, and 9 parsimony informative sites characteristics. Phylogenetic analysis using the matK gene sequence has more parsimony informative sites than genes in other chloroplasts (Müller et al., 2006; Barthet \& Hilu, 2007).

Table 1. Composition of nucleotides, $\mathrm{AT}$ and GC content of the matK gene sequence in Anaphalis longifolia

\begin{tabular}{|c|c|c|c|c|c|c|c|}
\hline Species & $\mathbf{T}$ & C & $\mathbf{A}$ & G & Total & GC (\%) & AT (\%) \\
\hline Anaphalis margaritacea (HQ594564) & 36.34 & 17.41 & 29.48 & 16.77 & 787 & 34.18 & 65.82 \\
\hline Helianthus annuus (AY215805.1) & 36.92 & 16.60 & 29.48 & 17.00 & 1506 & 33.60 & 66.40 \\
\hline Anaphalis aureopunctata (MH659925.1) & 36.88 & 17.36 & 29.28 & 16.48 & 789 & 33.84 & 66.16 \\
\hline Anaphalis aureopunctata (MH714290.1) & 36.38 & 17.49 & 29.58 & 16.55 & 852 & 34.04 & 65.96 \\
\hline Anaphalis sinica (MH659676.1) & 37.01 & 17.52 & 28.65 & 16.82 & 862 & 34.34 & 65.66 \\
\hline Anaphalis sinica (KX148081.1) & 37.28 & 16.24 & 30.05 & 16.44 & 1521 & 32.68 & 67.32 \\
\hline Anaphalis margaritacea (MG224815) & 36.53 & 17.24 & 29.63 & 16.60 & 783 & 33.84 & 66.16 \\
\hline Anaphalis margaritacea (HM445632) & 36.89 & 16.34 & 30.04 & 16.73 & 1518 & 33.07 & 66.93 \\
\hline Anaphalis longifolia & 36.32 & 17.68 & 29.51 & 16.49 & 837 & 34.17 & 65.83 \\
\hline Anaphalis longifolia (2) & 36.24 & 17.53 & 29.65 & 16.59 & 850 & 34.12 & 65.88 \\
\hline Average & 36.75 & 16.99 & 29.60 & 16.66 & 1030.5 & 33.65 & 66.35 \\
\hline
\end{tabular}

The results of the matK sequence analysis on A. longifolia show that the AT content was higher than the GC content in the Asteraceae family (Table 1). Variation in GC content is a key genome feature due to being closely related to the fundamental elements of genome organization in an organism (Eyre-Walker \& Hurst, 2001; Mukhopadhyay et al., 2007). Genomes rich in GC show higher gene density, higher mutation rates conservation level, and higher rates of recombination level compared to regions lacking in GC (Niu et al., 2017). GC content from 65 accessions of Edelweiss (Leontopodium) from the Himalayan/Tibet centre using nuclear ribosomal (ITS and ETS) and plastid (matK and trnL_F) sequences ranged from 43-52\% (Blöch et al., 2010). Anapalis selengensis genome has $37.46 \%$ GC content and 62.54\% AT content (Meng et al., 2019).

Table 2. Genetic distance between Anaphalis longifolia and species from the Anaphalis genus and the Asteraceae family 


\begin{tabular}{|c|c|c|c|c|c|c|c|c|c|c|}
\hline No & Species & 1 & 2 & 3 & 4 & $\mathbf{5}$ & 6 & 7 & 8 & 9 \\
\hline 1 & Anaphalis longifolia & 1 & & & & & & & & \\
\hline 2 & Anaphalis longifolia (2) & 0.000 & 1 & & & & & & & \\
\hline 3 & Anaphalis margaritacea (HQ594564) & 0.003 & 0.006 & 1 & & & & & & \\
\hline 4 & Anaphalis margaritacea (MG224815) & 0.001 & 0.001 & 0.000 & 1 & & & & & \\
\hline 5 & Anaphalis margaritacea (HM445632) & 0.006 & 0.009 & 0.000 & 0.000 & 1 & & & & \\
\hline 6 & Anaphalis aureopunctata (MH659925.1) & 0.006 & 0.006 & 0.005 & 0.005 & 0.005 & 1 & & & \\
\hline 7 & Anaphalis aureopunctata (MH714290.1) & 0.006 & 0.010 & 0.004 & 0.004 & 0.008 & 0.006 & 1 & & \\
\hline 8 & Anaphalis sinica (MH659676.1) & 0.009 & 0.012 & 0.006 & 0.006 & 0.006 & 0.001 & 0.008 & 1 & \\
\hline 9 & Anaphalis sinica (KX148081.1) & 0.011 & 0.014 & 0.005 & 0.005 & 0.006 & 0.000 & 0.011 & 0.001 & 1 \\
\hline 10 & Helianthus annuus (AY215805.1) & 0.070 & 0.074 & 0.069 & 0.070 & 0.072 & 0.072 & 0.069 & 0.067 & 0.074 \\
\hline
\end{tabular}

The genetic distance analysis of Anaphalis longifolia with species from the Anaphalis genus and the Asteraceae family showed that the distances between species in the genus Anaphalis ranged between 0-0.014 (Table 2). The highest variation was found in Anaphalis sinica and the lowest was in Anaphalis longifolia. The genetic distance between the Anaphalis genus and Helianthus annuus as an outgroup ranged from 0.067 to 0.074 . The genetic distance in the Leontopodium ITS region ranged from $0.2 \%$ to $6.8 \%$ (Blöch et al., 2010). A study by Ade et al. (2019) who analyzed the genetic distance of Anaphalis spp (A. javanica, A. longifolia, and $A$. viscida) based on molecular characteristics (ITS, ETS, and EST-SSR markers) showed that the genetic distance was between 0.004 to 0.040 , indicating small genetic distance between species in the Anaphalis genus.

Molecular-based research on Anaphalis has been successfully carried out using the internal transcribed spacer (ITS) marker (Glenny \& Wagstaff, 1997; Blöch et al., 2010) and external transcribed spacer (ETS) (Blöch et al., 2010; Nie et al., 2013; Ade et al., 2019), EST-SSR markers (Ade et al., 2019), trnL (Blöch et al., 2010; Kurniawan et al., 2014), and matK (Blöch et al., 2010). Molecular-based research on Anaphalis using the matK marker is still very rare. The matK gene is a marker that can be used as a DNA barcode and is recommended by Barcode of Life (CboL) for its consistent ability to show high discrimination level between angiosperm species) (Lahaye et al., 2008a).

In this study, the results of alignment of the $m a t K$ gene sequence from 9 data on Anaphalis genus indicated that there were 7 single nucleotide polymorphism (SNP) sites (Table 3), namely sites 492, 504, 505, 506, 1061, 1068, and 1176. In the $A$. longifolia species, no SNP site was detected. SNP for defined genetic location were determined in at least $1 \%$ of the population (Kim \& Misra, 2007). SNP is one of the stable genetic polymorphisms in a genome and can be used to analyze differences between closely related species (Germano \& Klein, 1999; Yamamoto et al., 2010). matK and rbcl showed high sequence quality, but only provided a few SNP sites (Huang et al., 2014) and therefore highly suitable for use in identifying species (Hollingsworth et al., 2009).

Table 3. Single nucleotide polymorphism in the Anaphalis genus

\begin{tabular}{lccccccc}
\hline & \multicolumn{7}{c}{ Nucleotide Base Site } \\
\cline { 2 - 7 } \multicolumn{1}{c}{ Sample } & & & & & 1 & 1 & 1 \\
& 9 & 5 & 5 & 5 & 0 & 0 & 1 \\
& 2 & 0 & 0 & 0 & 6 & 6 & 7 \\
A. margaritacea (HQ594564) & - & A & G & A & T & C & G \\
A. aureopunctata (MH659925.1) & - & - & - & - &. &. &. \\
A. aureopunctata (MH714290.1) & A &. &. &. & A & A &. \\
A. sinica (MH659676.1) & C &. &. &. &. &. & T \\
A. sinica (KX148081.1) & C &. &. &. &. &. &. \\
A. margaritacea (MG224815) & - & - & - & - &. &. &. \\
A. margaritacea (HM445632) & C &. &. &. &. &. &. \\
A. longifolia & - & - & - & - &. &. &. \\
A. longifolia (2) & - & G & A & T &. &. &. \\
\hline
\end{tabular}

In this study, the matK gene sequence in $A$. longifolia has the potentials to be used as DNA barcode. Lahaye et al. (2008) proposed that matK could potentially become DNA barcode in plants. The matK gene sequence is one of the fastest growing sequences of the plastid genome (Hilu \& Liang, 1997) and possibly the closest plant analogue to the COI gene sequence in animal DNA barcodes (Hollingsworth et al., 2011). The matK gene sequence can be very difficult to amplify by PCR using existing primary sets, especially in non-angiosperm plants (Hollingsworth et al., 2011).

DNA barcoding, which is widely applied in taxonomic research today, is invaluable for understanding species boundaries, community ecology, evolution and biodiversity conservation (Kress et al., 2015). Currently, conservationists have adopted DNA barcodes as a tool in the field of conservation (Chakraborty et al., 2014; Joly et al., 2014). DNA Barcoding enables the identification species boundaries to be used as clues in determining target conservation habitats (Faith, 1992). When the DNA barcode for each species is complete, comparative measure of phylogenetic diversity will become the standard metric for assessment in determining conservation strategies (Kress et al., 
Jurnal Biosains Vol. 6 No. 3 Desember 2020

DOI: https://doi.org/10.24114/jbio.v6i3.22403

2015). In addition, the development of DNA barcode research is also used for the identification and detection of illegally-traded endangered species (Lahaye et al., 2008b). There will be increased use of DNA barcode in the future, mainly because the available technology will become simpler and cheaper (Kress et al., 2015).

\section{Conclusion}

The results showed that the matK gene sequence can be amplified at a length of $800-850 \mathrm{bp}$. In the A. longifolia matK gene sequence, the AT content was higher than the GC content. The resulting genetic distance ranged between 0-0.0014. The alignment results of the matK gene sequence showed that there are 1521 observable characteristics, including 1403 conserved site characteristics, 118 site variable characteristics, 9 parsimony informative site characteristics, and 7 single nucleotide polymorphism (SNP) site characteristics. This suggests that the matK gene sequence has the potential for development as DNA barcoding to identify A. longifolia.

\section{References}

Abbas, B., Kabes, R.J., Mawikere, N.L., Ruimassa, R.M.R. \& MATURBONG, R.A. 2020. DNA barcode of Metroxylon sagu and others palm species using matK gene. Biodiversitas Journal of Biological Diversity, 21(9). Avaiable https://smujo.id/biodiv/article/view/5916.

Ade, F.Y., Hakim, L., Arumingtyas, E.L. \& Azrianingsih, R. 2019. The Detection of Anaphalis spp. Genetic Diversity Based on Molecular Character (using ITS, ETS, and EST-SSR markers). International Journal on Advanced Science, Engineering and Information Technology, 9(5): 1695. Avaiable in http://ijaseit.insightsociety.org/index.php?option=c om_content\&view=article\&id=9\&Itemid=1\&article_i $\mathrm{d}=9597$.

Aliadi, A., Evrizal, A.M.Z. \& Edje, D. 1990. Kemungkinan penangkaran edelweis (Anaphalis javanica (Bl.) Boerl.) dengan stek batang. Media Konservasi, 3(1): 37-45.

Amandita, F.Y., Rembold, K., Vornam, B., Rahayu, S., Siregar, I.Z., Kreft, H. \& Finkeldey, R. 2019. DNA barcoding of flowering plants in Sumatra, Indonesia. Ecology and Evolution, 9(4): 1858-1868. Avaiable in http://doi.wiley.com/10.1002/ece3.4875.

Arif, M.F., Aristya, G.R., Subositi, D., Sari, A.N. \& Kasiamdari, R.S. 2019. Short Communication: rbcL and matK chloroplast DNA composition of green chireta (Andrographis paniculata) from Indonesia. Biodiversitas Journal of Biological Diversity, 20(12). Avaiable https://smujo.id/biodiv/article/view/4601.

Backer, C.A. \& van den Brink, R.C.B. 1965. Flora of Java.
ISSN 2443-1230 (cetak)

ISSN 2460-6804 (online)

Groninge: NVP Noordhoff.

Barthet, M.M. \& Hilu, K.W. 2007. Expression of matK: functional and evolutionary implications. American Journal of Botany, 94(8): 1402-1412. Avaiable in http://doi.wiley.com/10.3732/ajb.94.8.1402.

Blöch, C., Dickoré, W.B., Samuel, R. \& Stuessy, T.F. 2010. Molecular Phylogeny of The Edelweiss ( Leontopodium, Asteraceae-Gnaphalieae). Edinburgh Journal of Botany, 67(2): 235-264. Avaiable in https://www.cambridge.org/core/product/identifi er/S0960428610000065/type/journal_article.

Chakraborty, C., Doss, C.G.P., Patra, B.C. \& Bandyopadhyay, S. 2014. DNA barcoding to map the microbial communities: current advances and future directions. Applied Microbiology and Biotechnology, 98(8): 3425-3436. Avaiable in http://link.springer.com/10.1007/s00253-0145550-9.

Chanchani, P., Rawat, G.S. \& Goyal, S.P. 2011. Biodiversity of Sikkim-Exploring and Conserving a Global Hotspot. Information and Public Relations Department, Government of Sikkim. Biodiversity of SikkimExploring and Conserving a Global Hotspot. Information and Public Relations Department, Government of Sikkim, 351-362.

Dean, G.H., Asmarayani, R., Ardiyani, M., Santika, Y., Triono, T., Mathews, S. \& Webb, C.O. 2018. Generating DNA sequence data with limited resources for molecular biology: Lessons from a barcoding project in Indonesia. Applications in Plant Sciences, 6(7): e01167. Avaiable in http://doi.wiley.com/10.1002/aps3.1167.

Eyre-Walker, A. \& Hurst, L.D. 2001. The evolution of isochores. Nature Reviews Genetics, 2(7): 549-555. Avaiable

in http://www.nature.com/articles/35080577.

Faith, D.P. 1992. Conservation evaluation and phylogenetic diversity. Biological Conservation, 61(1): 1-10. Avaiable in https://linkinghub.elsevier.com/retrieve/pii/00063 20792912013.

Fazekas, A.J., Burgess, K.S., Kesanakurti, P.R., Graham, S.W., Newmaster, S.G., Husband, B.C., Percy, D.M., Hajibabaei, M. \& Barrett, S.C.H. 2008. Multiple Multilocus DNA Barcodes from the Plastid Genome Discriminate Plant Species Equally Well. PLOS ONE, 3(7): e2802. Avaiable in https://dx.plos.org/10.1371/journal.pone.0002802.

Felsenstein, J. 1985. Confidence Limits on Phylogenies: An Approach Using the Bootstrap. Evolution, 39(4): 783-791.

Avaiable in http://doi.wiley.com/10.1111/j.15585646.1985.tb00420.x.

Francis, C.M., Borisenko, A. V., Ivanova, N. V., Eger, J.L., Lim, B.K., Guillén-Servent, A., Kruskop, S. V., Mackie, I. \& Hebert, P.D.N. 2010. The Role of DNA Barcodes in Understanding and Conservation of Mammal Diversity in Southeast Asia. PLoS ONE, 5(9): e12575. Avaiable

in https://dx.plos.org/10.1371/journal.pone.0012575. 
Jurnal Biosains Vol. 6 No. 3 Desember 2020

DOI: https://doi.org/10.24114/jbio.v6i3.22403

Germano, J. \& Klein, A.S. 1999. Species-specific nuclear and chloroplast single nucleotide polymorphisms to distinguish Picea glauca, P. mariana and P. rubens. Theoretical and Applied Genetics, 99(1-2): 37-49. Avaiable

in http://link.springer.com/10.1007/s001220051206.

Glenny, D. \& Wagstaff, S. 1997. Evolution and biogeography of New Zealand Anaphalis (Asteraceae: Gnaphalieae) inferred from rDNA sequences. New Zealand Journal of Botany, 35(4): 441-449. Avaiable in http://www.tandfonline.com/doi/abs/10.1080/00 28825X.1987.10410169.

Global Forest Watch 2020. Indonesia Deforestation Rates \& Statistics. Word Resources Institute. Avaiable in https://www.globalforestwatch.org/dashboards/co untry/IDN.

Harnelly, E., Thomy, Z. \& Fathiya, N. 2018. Phylogenetic analysis of Dipterocarpaceae in Ketambe Research Station, Gunung Leuser National Park (Sumatra, Indonesia) based on rbcL and matK genes. Biodiversitas Journal of Biological Diversity, 19(3): 1074-1080. Avaiable

in

http://biodiversitas.mipa.uns.ac.id/D/D1903/D190 340.pdf.

Hilu, K.W. \& Liang, G. 1997. The matK gene: sequence variation and application in plant systematics. American Journal of Botany, 84(6): 830-839. Avaiable in http://doi.wiley.com/10.2307/2445819.

Hollingsworth, P.M., Forrest, L.L., Spouge, J.L., Hajibabaei, M., Ratnasingham, S., van der Bank, M., Chase, M.W., Cowan, R.S., Erickson, D.L., Fazekas, A.J., Graham, S.W., James, K.E., Kim, K.-J., Kress, W.J., Schneider, H., van AlphenStahl, J., Barrett, S.C.H., van den Berg, C., Bogarin, D., Burgess, K.S., Cameron, K.M., Carine, M., Chacon, J., Clark, A., Clarkson, J.J., Conrad, F., Devey, D.S., Ford, C.S., Hedderson, T.A.J., Hollingsworth, M.L., Husband, B.C., Kelly, L.J., Kesanakurti, P.R., Kim, J.S., Kim, Y.-D., Lahaye, R., Lee, H.-L., Long, D.G., Madrinan, S., Maurin, O., Meusnier, I., Newmaster, S.G., Park, C.W., Percy, D.M., Petersen, G., Richardson, J.E., Salazar, G.A., Savolainen, V., Seberg, O., Wilkinson, M.J., Yi, D.K. \& Little, D.P. 2009. A DNA barcode for land plants. Proceedings of the National Academy of Sciences, 106(31): 12794-12797. Avaiable in http://www.pnas.org/cgi/doi/10.1073/pnas.09058 45106.

Hollingsworth, P.M., Graham, S.W. \& Little, D.P. 2011. Choosing and Using a Plant DNA Barcode. PLoS ONE, 6(5): e19254. Avaiable in https://dx.plos.org/10.1371/journal.pone.0019254.

Huang, Q., Duan, Z., Yang, J., Ma, X., Zhan, R., Xu, H. \& Chen, W. 2014. SNP Typing for Germplasm Identification of Amomum villosum Lour. Based on DNA Barcoding Markers. PLoS ONE, 9(12): e114940. Avaiable in https://dx.plos.org/10.1371/journal.pone.0114940.

Joly, S., Davies, T.J., Archambault, A., Bruneau, A., Derry, A., Kembel, S.W., Peres-Neto, P., Vamosi, J. \& Wheeler, T.A. 2014. Ecology in the age of DNA barcoding: the resource, the promise and the challenges ahead. Molecular Ecology Resources, 14(2): 221-232.
ISSN 2443-1230 (cetak)

ISSN 2460-6804 (online)

Avaiable in http://doi.wiley.com/10.1111/17550998.12173.

Kim, S. \& Misra, A. 2007. SNP Genotyping: Technologies and Biomedical Applications. Annual Review of Biomedical Engineering, 9(1): 289-320. Avaiable in http://www.annualreviews.org/doi/10.1146/annu rev.bioeng.9.060906.152037.

Kimura, M. 1980. A simple method for estimating evolutionary rates of base substitutions through comparative studies of nucleotide sequences. Journal of Molecular Evolution, 16(2): 111-120. Avaiable in http://link.springer.com/10.1007/BF01731581.

Koster, J.T.H. 1941. Notes on Malay Compositae. Blumea, 4(3): 482-492.

Kress, W.J., García-Robledo, C., Uriarte, M. \& Erickson, D.L. 2015. DNA barcodes for ecology, evolution, and conservation. Trends in Ecology \& Evolution, 30(1): 25-35. Avaiable in https://linkinghub.elsevier.com/retrieve/pii/S0169 534714002274.

Krishna Krishnamurthy, P. \& Francis, R.A. 2012. A critical review on the utility of DNA barcoding in biodiversity conservation. Biodiversity and Conservation, 21(8): 1901-1919. Avaiable http://link.springer.com/10.1007/s10531-0120306-2.

Kumar, S., Stecher, G., Li, M., Knyaz, C. \& Tamura, K. 2018. MEGA X: Molecular Evolutionary Genetics Analysis across Computing Platforms. Molecular Biology and Evolution, 35(6): 1547-1549. Avaiable in https://academic.oup.com/mbe/article/35/6/1547 /4990887.

Kurniawan, L.H., Hakim, L. \& Arumingtyas, E.L. 2014. Kurniawan, L. H., Hakim, L., \& Arumingtyas, E. L. (2014). Effectiveness of trnL (UAA) intron sequence for detecting genetic variation of Anaphalis spp. along Mount Semeru hiking track, Bromo Tengger Semeru National Park Indonesia. Journal of Biodiversity and Environmental Sciences, 5(1): 501507.

Kuzmina, M.L., Johnson, K.L., Barron, H.R. \& Hebert, P.D. 2012. Identification of the vascular plants of Churchill, Manitoba, using a DNA barcode library. BMC Ecology, 12(1): 25. Avaiable in http://bmcecol.biomedcentral.com/articles/10.118 6/1472-6785-12-25.

Lahaye, R., van der Bank, M., Bogarin, D., Warner, J., Pupulin, F., Gigot, G., Maurin, O., Duthoit, S., Barraclough, T.G. \& Savolainen, V. 2008a. DNA barcoding the floras of biodiversity hotspots. Proceedings of the National Academy of Sciences, 105(8): 2923-2928. Avaiable in http://www.pnas.org/cgi/doi/10.1073/pnas.07099 36105.

Lahaye, R., Van der Bank, M., Maurin, O., Duthoit, S. \& Savolainen, V. 2008b. A DNA barcode for the flora of the Kruger National Park (South Africa). South African Journal of Botany, 74(2): 370-371. Avaiable in https://linkinghub.elsevier.com/retrieve/pii/S0254 62990800077X. 
Jurnal Biosains Vol. 6 No. 3 Desember 2020

DOI: https://doi.org/10.24114/jbio.v6i3.22403

Li, D.-Z., Gao, L.-M., Li, H.-T., Wang, H., Ge, X.-J., Liu, J.-Q., Chen, Z.-D., Zhou, S.-L., Chen, S.-L., Yang, J.-B., Fu, C.X., Zeng, C.-X., Yan, H.-F., Zhu, Y.-J., Sun, Y.-S., Chen, S.Y., Zhao, L., Wang, K., Yang, T. \& Duan, G.-W. 2011. Comparative analysis of a large dataset indicates that internal transcribed spacer (ITS) should be incorporated into the core barcode for seed plants. Proceedings of the National Academy of Sciences, 108(49): 19641-19646. Avaiable in http://www.pnas.org/cgi/doi/10.1073/pnas.11045 51108.

Meng, D., Xiaomei, Z., Wenzhen, K. \& Xu, Z. 2019. Detecting useful genetic markers and reconstructing the phylogeny of an important medicinal resource plant, Artemisia selengensis, based on chloroplast genomics. PLOS ONE, 14(2): e0211340. Avaiable in https://dx.plos.org/10.1371/journal.pone.0211340.

Mukhopadhyay, P., Basak, S. \& Ghosh, T.C. 2007. Nature of selective constraints on synonymous codon usage of rice differs in GC-poor and GC-rich genes. Gene, 400(1-2): 71-81. Avaiable in https://linkinghub.elsevier.com/retrieve/pii/S0378 111907003009.

Müller, K.F., Borsch, T. \& Hilu, K.W. 2006. Phylogenetic utility of rapidly evolving DNA at high taxonomical levels: Contrasting matK, trnT-F, and rbcL in basal angiosperms. Molecular Phylogenetics and Evolution, 41(1): 99-117. Avaiable in https://linkinghub.elsevier.com/retrieve/pii/S1055 790306002624.

Nie, Z.-L., Funk, V., Sun, H., Deng, T., Meng, Y. \& Wen, J. 2013. Molecular phylogeny of Anaphalis (Asteraceae, Gnaphalieae) with biogeographic implications in the Northern Hemisphere. Journal of Plant Research, 126(1): 17-32. Avaiable in http://link.springer.com/10.1007/s10265-0120506-6.

Niu, Z., Xue, Q., Wang, H., Xie, X., Zhu, S., Liu, W. \& Ding, X. 2017. Mutational Biases and GC-Biased Gene Conversion Affect GC Content in the Plastomes of Dendrobium Genus. International Journal of Molecular Sciences, 18(11): 2307. Avaiable in http://www.mdpi.com/1422-0067/18/11/2307.

Prakasa, H., Akmal, A.Z., Guci, W.A. \& Edi, S. 2018. Analisis Habitat (Anaphalis longifolia (Blume) Blume ex DC.) di Sumatera Utara. Jurnal Biosains, 4(2): 78. Avaiable in

http://jurnal.unimed.ac.id/2012/index.php/biosain s/article/view/10254.

Saarela, J.M., Sokoloff, P.C., Gillespie, L.J., Consaul, L.L. \& Bull, R.D. 2013. DNA Barcoding the Canadian Arctic Flora:
ISSN 2443-1230 (cetak)

ISSN 2460-6804 (online)

Core Plastid Barcodes $(\mathrm{rbcL}+$ matK) for 490 Vascular Plant Species. PLoS ONE, 8(10): e77982. Avaiable in https://dx.plos.org/10.1371/journal.pone.0077982.

Smissen, R.D., Galbany-Casals, M. \& Breitwieser, I. 2011. Ancient allopolyploidy in the everlasting daisies (Asteraceae: Gnaphalieae): Complex relationships among extant clades. TAXON, 60(3): 649-662. Avaiable

in http://doi.wiley.com/10.1002/tax.603003.

TALLEI, T.E. \& KOLONDAM, B.J. 2015. DNA Barcoding of Sangihe Nutmeg ( Myristica fragrans ) using mat K Gene. HAYATI Journal of Biosciences, 22(1): 41-47. Avaiable in https://linkinghub.elsevier.com/retrieve/pii/S1978 301916300729.

Taufiq, A., Syamsuardi, S., Arbain, A. \& Maideliza, T. 2013. Analisis Morfometri dan Biologi Reproduksi Anaphalis Javanica dan A. Longifolia (Asteraceae) di Sumatera Barat. Floribunda, 4(7): 161-168.

Techen, N., Parveen, I., Pan, Z. \& Khan, I.A. 2014. DNA barcoding of medicinal plant material for identification. Current Opinion in Biotechnology, 25: 103-110. Avaiable in https://linkinghub.elsevier.com/retrieve/pii/S0958 166913006721.

Tjitrosoedirdjo, S.S. 2002. Notes on the Asteraceae of Sumatera. BIOTROPIA-The Southeast Asian Journal of Tropical Biology, 19: 65-84.

Topik, H., Yukawa, T. \& Ito, M. 2005. Molecular phylogenetics of subtribe Aeridinae (Orchidaceae): insights from plastid matK and nuclear ribosomal ITS sequences. Journal of Plant Research, 118(4): 271$284 . \quad$ Avaiable in http://link.springer.com/10.1007/s10265-0050217-3.

Ward, J., Bayer, R., Breitwieser, I., Smissen, R., Galbany, M. \& Unwin, M. 2009. Gnaphalieae. Systematic. Vienna: IAPT, hal.539-588.

Wattoo, J.I., Saleem, M.Z., Shahzad, M.S., Arif, A., Shahzad, A. \& Saleem, M.A. 2016. DNA Barcoding: Amplification and sequence analysis of $\mathrm{rbcl}$ and matK genome regions in three divergent plant species. Advancements in Life Sciences, 4(1): 3-7.

Yamamoto, T., Nagasaki, H., Yonemaru, J., Ebana, K., Nakajima, M., Shibaya, T. \& Yano, M. 2010. Fine definition of the pedigree haplotypes of closely related rice cultivars by means of genome-wide discovery of single-nucleotide polymorphisms. $B M C$ Genomics, 11(1): 267. Avaiable in http://bmcgenomics.biomedcentral.com/articles/1 0.1186/1471-2164-11-267. 